\title{
Design and Implementation of Protection Relay 3 Phase Induction Motor
}

\author{
$1^{\text {st }}$ Kukuh Widarsono \\ Lecture in Electrical Industrial \\ Engineering \\ State Polytechnic of Madura \\ Sidoarjo, Indonesia \\ kukuh.widarsono@gmail.com
}

\author{
$2^{\text {nd }}$ Abdillah Fashiha Ilman \\ Lecture in Electrical Industrial \\ Engineering \\ State Polytechnic of Madura \\ Sampang, Indonesia \\ abdifashiha@gmail.com
}

\author{
$3^{\text {rd }}$ Alfian Rejeki \\ Student in Electrical Industrial \\ Engineering \\ State Polytechnic of Madura line 4: \\ Bojonegoro, Indonesia \\ alfianrejeki98@gmail.com
}

\begin{abstract}
Damage to the electrical components will inevitably occur. It could be caused by several factors either from inside and outside the system. 3 phase induction motor is the most commonly used in industry, but the problems such as over current and overheat on the motor are still found. They can cause fatal damage to the motor. Therefore, a relay protection system which utilizes a microcontroller has been made to protect the 3 phase induction motors. This relay protection is designed differently from conventional relay protection which commonly used in industry. It is designed based on the microcontroller control and is accompanied by setting and reset facilities respectively to display on the LCD via Push Buttons. As such, 3 phase induction motors are protected from severe damage caused by interference from the mesh source. It is expected to reduce the damage of the 3 phase induction motor.
\end{abstract}

Keywords: 3 phase induction motor, Microcontroller, Over current and over heat.

\section{INTRODUCTION}

In the current era of globalization, the use of 3 phase induction motors in the industry is growing rapidly. This development is due to the advantages of 3 phase induction motor which are not possessed by other types of motors, including sturdy construction, low maintenance, and high efficiency. Besides, this type of motor has a constant speed with frequency and voltage based. Because of its functions and advantages, 3 phase induction motors are widely applied in the industrial world as large-scale movers that require constant power and speed.

3 phase induction motor does not always work normally, some problems arise as a result of ignoring the early system planning. Problems that arise such as irregular maintenance, the use of a 3 phase induction motor continuously, the lack of a 3 phase induction motor control system, over current or over current and overload so that the motor experiences overheating or overheating and many other disturbances. When a 3 phase induction motor functions as a drive, heat will arise on the motor windings due to its energy. This energi is not only converted into motion energy but there is also some energy which is around $10-20 \%$ in dissipation into heat which is known as motor losses. These disturbances cause the motor to suffer fatal damage that disrupts the system that has been running in an industrial process. The existence of these problems, there are several studies examining the safety of 3-phase induction motors, including in 2013 research with the title Temperature Measurement Techniques of Induction Motor Windings Using Resistance Method described securing the motor from excessive temperatures on the motor windings. The excessive result of this research is more accurate temperature measurement, then the method used to measure the resistance value of the motor windings and convert into temperature increases on the motor [1-2]. Furthermore, in 2014 research with the title Design Safety Relay Builds to Overcome 3 Phase Induction Motor Disorders, this study secures overload and over-voltage disturbances, further the advantages of this research are the system works in accordance with what has been set, and the method used is to compare the value of the setpoint and parameter values of both current and voltage passing through the system [3]. Next in 2015, entitled Design and Construction of a 3 Phase Motor Overcurrent Protection System with Start and Trip Timers, this research focuses on overcurrent 3 phase induction motor, then the advantages of this safety are accompanied by start and trip timers and the method used in comparing results testing with calculations [4-5]. Other developmental research is in 2018 under the title Design Control System and Electric Motor Protection System for Heat (overheating) and Early Warning for Voltage and Current Disorders Based on Atmega 328, which focus on temperature disturbances (overheat), then the excess is accompanied by early warning alarm against interference, and the method used is to compare the temperature value on the motor with a predetermined setpoint value [6-7].

Based on the result of the previous studies above, this research will be made to contribute to the safety relay in those previous studies. From the problems and shortcomings that still exist, a safety system was created with the title "Design and Implementation of 3 Phase Induction Motor Safety Relay". This safety system has advantages including Speed (Speed), Accuracy (Selective), Reliability (Reapibility), and Sensitivity (Sensitive). Then the method used is to compare the value of current and temperature obtained with a predetermined set point. Furthermore, this safety will work automatically based on input data from over current and over temperature in the motor windings, then the relay will disconnect or turn off the motor from the voltage source automatically so that the motor will avoid the risk of fatal damage, and the rotating speed of the motor will be displayed on the LCD to know how fast the motor is spinning. 


\section{System CONFIGURATION}

In the design of a 3 phase induction motor safety system against overcurrent (Over Current) and excess temperature (Over Heat) and displaying the motor rotational speed will be designed as it is seen in a block diagram below.

Normal condition is when the current value, voltage and temperature in the motor as the name plate. In this condition, the sensor just transmit the current data, voltage and temperature to be displayed on the LCD. In vice versa, if there is an overcurrent disturbance (over current), the sensor will detect and send it to the control in the form of Arduino Mega to provide logic 0 on the relay. Next, the relay will contact the contactor to disconnect the voltage source. Hence, the voltage flow to the motor is cut off and the motor stops.

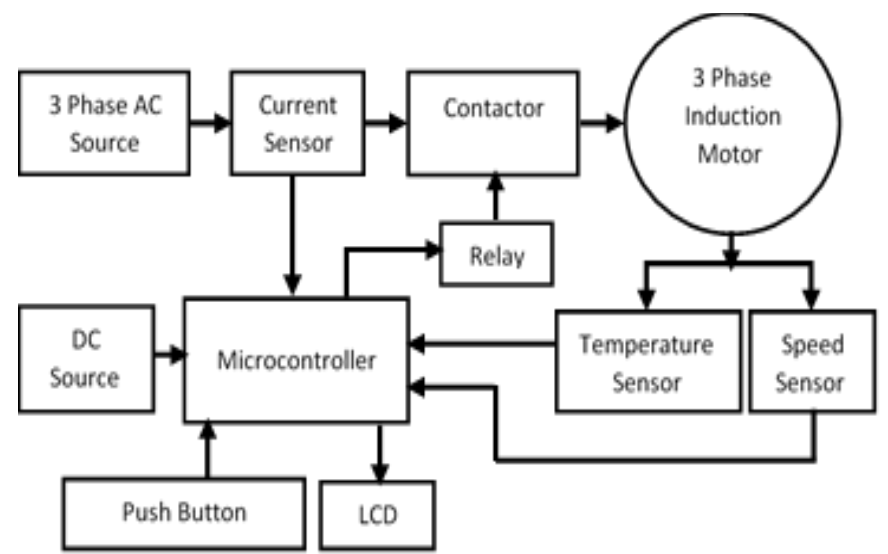

Fig. 1. Block Diagram Protection Relay 3 Phase Induction Motor

\section{A. Design and Manufacture of Current Sensor}

CT sensor is a current AC sensor that functions to read the current used by a 3 phase induction motor whether the current needed by the motor is in accord to its capacity or not.

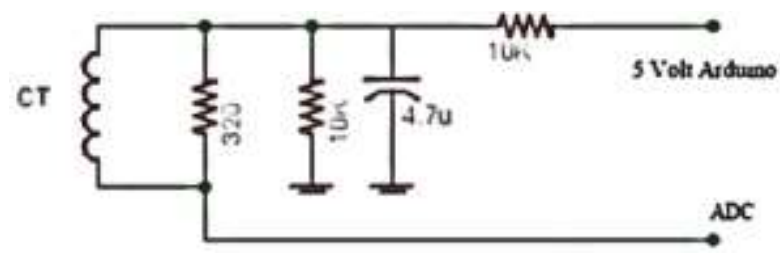

Fig. 2. Current Sensor Circuit

\section{B. Design and Manufacture of Temperature Sensor}

NTC (Negative Temperature Coefficient) thermistor is an electronic component that is sensitive to the surrounding temperature. Thermistor operating temperatures is generally range between $-90^{\circ} \mathrm{C}$ to $130^{\circ} \mathrm{C}$. The circuit of this component is connected in series with a $100 \mathrm{k}$ ohm resistor, as it is seen in Figure 3.5. a series of temperature sensors.

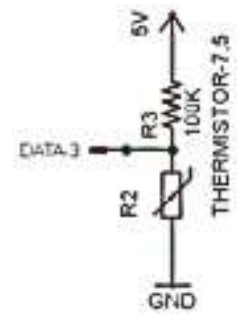

Fig. 3. Temperature Sensor Circui
In this case, the use of NTC Thermistor sensor refers to the NEMA Standard (The National Electrical Manufacture Association) Insulation Class or insulation class is a grouping or division of classes for the resistance of the wire coil of an electromotor at a certain temperature/temperature. This standard divides Insulation Class into 4 including Insulation Class A, Insulation Class B, Insulation Class F, Insulation Class $\mathrm{H}$. In this case a 3 phase induction motor that works at a frequency of $50 \mathrm{~Hz}$ is included in Insulation Class F. where the maximum operational temperature is allowed in $155^{\circ}$ and the hottest Hot spot or temperature point increases by $10^{\circ}$. The maximum permissible operating temperature is obtained from the sum of the ambient temperature values $\left(40^{\circ}\right)$ plus the rising temperature or the increase in the permissible temperature plus the hot spot [5].

In this research, the NTC was installed on the stator winding. In the induction motor, the winding stator is a winding that is directly connected to the AC source. It to get the actual temperature value of the motor.

\section{Design and Manufacture of Speed Sensor}

The working principle of the Optocoupler sensor or speed sensor is that when a light source is given a voltage of 5 volts and produces light, the light entering the photodiode is not obstructed. In this condition, it will produce a voltage of 5 volts. The vice versa is when it is obstructed, it will produce a voltage of 0 volts where the voltage is the input from the microcontroller. Here is Figure 3.6 speed sensor circuit.

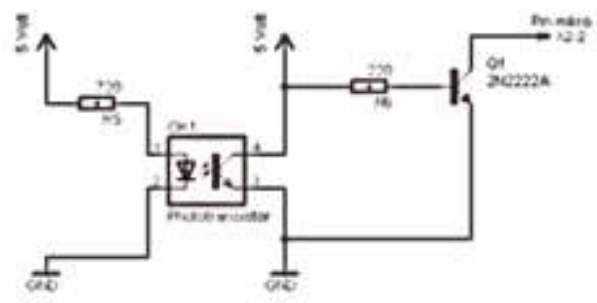

Fig. 4. Speed Sensor Circuit

\section{3 PHASE INDUCTION MOTOR}

The result of testing of 3 phase induction motor safety system and data obtained from the reading of 3 phase induction motor test equipment with equipment used are included:

- DC Generator Load

- Multimeter Measuring Device.

- Tachometer Measuring Device

- Digital Thermometer Device.

- The time needed for the temperature to reach the current limit using a stopwatch.

TABLE I. SPECIFICATION 3 PHASE INDUCTION MOTOR

\begin{tabular}{|l|l|}
\hline Type & YR114A \\
\hline Power (Watt) & 100 \\
\hline Voltage (Volt) & 380 \\
\hline Speed (RPM) & 1400 \\
\hline Connection From & $\mathrm{Y}$ \\
\hline
\end{tabular}




\section{TESTING AND ANALYSIS}

\section{A. Sensor ZMCT103C Testing}

Testing the current sensor is aimed to find out whether the sensor works or not. Then it is compared to the reading of the measuring instrument. The result of testing using resistor load resistance $(\mathrm{R})$ with $\mathrm{AC}$ input voltage showed that it made varies.

$$
\% \text { Error }=\frac{\text { measurement result-sensor result }}{\text { measurement result }} \times 100 \%
$$

Meanwhile, to find out the average percent error used the following formula :

$$
\text { Mean Error }=\frac{\sum \% \text { Error }}{\mathrm{N}}
$$

\begin{tabular}{|c|c|c|c|c|c|}
\hline No & $\begin{array}{l}\text { V } \\
\text { (Volt) }\end{array}$ & $\begin{array}{l}\mathrm{R} \\
(\mathrm{Ohm})\end{array}$ & $\begin{array}{l}\text { I } \\
\text { (Measurement) }\end{array}$ & $\begin{array}{l}\text { I } \\
\text { (Sensor) }\end{array}$ & $\begin{array}{l}\% \\
\text { Error }\end{array}$ \\
\hline 1. & \multirow{5}{*}{220} & 103 & 2,092 & 2,09 & 0,095 \\
\hline 2. & & 180 & 1,2 & 1,209 & 0,75 \\
\hline 3. & & 240 & 0,892 & 0,893 & 0,112 \\
\hline 4. & & 360 & 0,6 & 0,6 & 0 \\
\hline 5. & & 720 & 0,3 & 0,305 & 1,666 \\
\hline \multicolumn{5}{|c|}{ Mean \% Error } & 0.524 \\
\hline
\end{tabular}

TABLE II. SPECIFICATION 3 PHASE INDUCTION MOTOR

From Table 2. we can find out the percent error value of the ZMCT103C current sensor with resistor load (R) and the input voltage set at $220 \mathrm{~V}$. The value is compared with a multimeter and the percent error value is obtained based on the formula equation 4.1 and the average percent error (Mean error) is obtained based on equation 4.2 .

\section{B. Thermistor NTC Temperature Sensor Testing}

The NTC Thermistor sensor test is used as a parameter value compared to the current value which will then be used as a command to decide the voltage to the motor in case of Over Current and Over Heat. As a comparison value, the sensor will be tested at the same boiling water temperature and will be compared with a Digital Thermometer. it can find out how fast the motor is spinning. The result of testing the optocoupler sensor value will be compared toh the value of the tachometer.

TABLE IV. SPEED SENSOR TESTING

Based on the speed sensor testing in Table 4. shows the motor speed when under normal circumstances, the speed

\begin{tabular}{|l|l|l|l|l|}
\hline No & Testing & Optocouple & Tachometer & \% Error \\
\hline $1 . \quad \begin{array}{l}\text { Motor without } \\
\text { Load }\end{array}$ & 1497 & 1491 & 0.400 \\
\hline $2 . \quad \begin{array}{l}\text { Motor with } \\
\text { load }\end{array}$ & 1470 & 1484 & 0.952 \\
\hline \multicolumn{2}{|l}{ Mean \% Error } & 0.676 \\
\hline
\end{tabular}

is in line with the speed on the nameplate which is approximately 1400 RPM, but when the motor is burdened by the generator without the load speed shows a decrease in the RPM value, as shown in Table 4. Where the percent error value is obtained based on equation (1) and the mean percent error (Mean) is obtained based on the equation (2).

\section{1) NTC Sensor}

In Table 3. a calibration of the NTC Thermistor sensor with a Digital Thermometer, which is tested under the same conditions that are the temperature of boiling water with the level of heat from the maximum temperature to the minimum temperature. The trial still has a percent error value. Where the percent error value is obtained based on the equation (1) and the average percent error (Mean) is obtained based on equation (2) [8].

\begin{tabular}{|c|c|c|c|c|c|c|}
\hline No. & $\begin{array}{l}\text { Temperature } \\
\text { Parameters }\end{array}$ & $\begin{array}{l}\text { Voltage Output } \\
N T C(\mathrm{~V})\end{array}$ & $\begin{array}{l}\text { Time } \\
\text { (Minute) }\end{array}$ & $\begin{array}{l}\text { Digital Thermometer } \\
\left({ }^{\circ} \mathrm{C}\right)\end{array}$ & Sensor NTC $\left({ }^{\circ} \mathrm{C}\right)$ & $\%$ Error \\
\hline \multirow{11}{*}{1.} & \multirow{11}{*}{$\begin{array}{l}\text { Boiling Water } \\
\text { Temperature }\end{array}$} & 0.425 & 0 & 65.4 & 61.85 & 5.4 \\
\hline & & 0.450 & 1 & 64.5 & 59.85 & 7.2 \\
\hline & & 0.500 & 2 & 63.0 & 56.85 & 9.7 \\
\hline & & 0.550 & 3 & 60.2 & 54.85 & 8.8 \\
\hline & & 0.558 & 4 & 57.0 & 53.85 & 5.5 \\
\hline & & 0.600 & 5 & 54.3 & 51.85 & 4.5 \\
\hline & & 0.650 & 6 & 53.5 & 50.85 & 4.9 \\
\hline & & 0.657 & 7 & 51.8 & 49.85 & 3.7 \\
\hline & & 0.700 & 8 & 50.6 & 48.85 & 3.4 \\
\hline & & 0.725 & 9 & 49.3 & 47.85 & 2.9 \\
\hline & & 0.750 & 10 & 48.3 & 46.85 & 3.0 \\
\hline \multicolumn{6}{|c|}{ Rata-Rata \% Error } & 6.35 \\
\hline
\end{tabular}

TABLE III. THERMISTOR NTC SENSOR TESTING

\section{Optocoupler Speed Sensor Testing}

This optocoupler sensor test aims to determine the speed of the motor and will be displayed on the LCD so that

\section{Circuit Breaker Testing}

The termination test in question is testing the motor circuit breaker whether it is working by a system that has 
been set up in the microcontroller program or not. In this circuit breaker is composed of relay drivers and contactors.

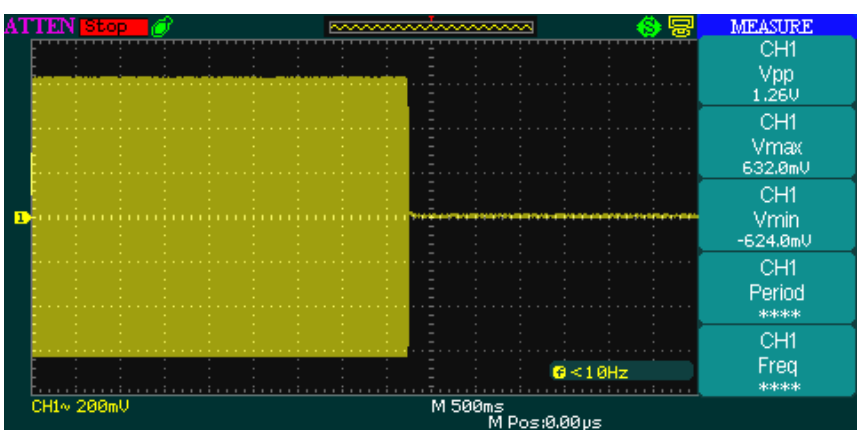

Fig. 5. Termination Signal Testing

In Figure 5. is the termination signal from the lamp load at a voltage source of $220 \mathrm{VAC}$, with a Vpp value of $1.26 \mathrm{~V}$ and a Vmax of $632 \mathrm{mV}$. The signal shows the response when a motor run and the motor stop. The following is the result of the termination trial data.

In Table 5. The test data will be explained in a 3 phase motor with 100 Watt power working at a frequency of $50 \mathrm{~Hz}$. In this case the Imax from the motor can be limited according to the maximum current specifications on the 3 phase motor, at the standby position the current value read by the sensor is 0,000 A to $0.002 \mathrm{~A}$. In this experiment Imax is set as much as 3 times the settings as in Table 4.2. while the motor current that is read by the sensor is $0.147 \mathrm{~A}, 0.151 \mathrm{~A}, 0.149 \mathrm{~A}$ so that the setting that successfully disconnects the motor is the first and second with a current value of $0.145 \mathrm{~A}$ and $0.150 \mathrm{~A}$. This is because of the setting current is smaller than the current in the motor, resulting in the occurrence of the disconnection response by the relay and the motor stops. The third setting of $0.155 \mathrm{~A}$ fails to respond to disconnection because the current motor does not exceed the current setting. testing. DC generator load and variations of this containment value of the motor current that is read by the sensor follows how much loading and holding on the motor as well as following the predetermined setting currents, In this case, the disconnection response time at the setting current $0.145 \mathrm{~A}$ is $1.27(\mathrm{~ms})$, and at the setting current $0.150 \mathrm{~A}$ has an interval of 1.03 (ms). While the motor speed remains normal at 1497 RPM.

Thus, all settings successfully break the motor that is equal to $0.21 \mathrm{~A}, 0.235 \mathrm{~A}$ and $0.24 \mathrm{~A}$. The test aims to find out whether the whole tool systems can work simultaneously with current and temperature conditions that have been set. Then how the speed response to time and temperature to time posed on the motor. The test shows that all tool systems can work in line with the provisions given. In this case, the termination response time is 1.03 (ms) to 1.27 (ms), or it can be said that the termination response is the same as a motor without a load.

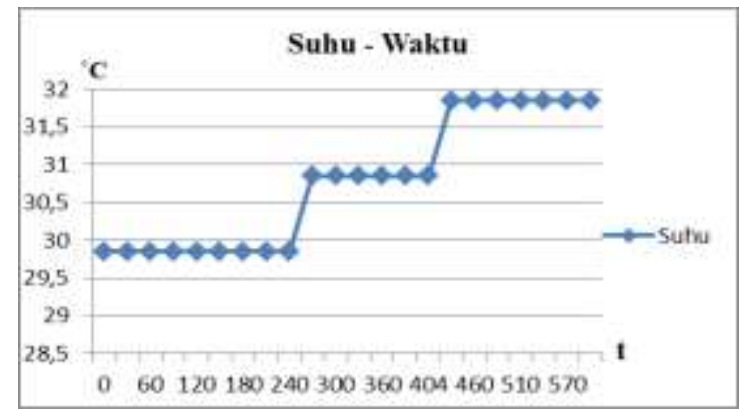

Fig. 6. The temperature graph at current settings $0.21 \mathrm{~A}$

In Figure 6. shows a graph of the temperature of the disconnection time at the current setting $0.21 \mathrm{~A}$. The graph starts from normal temperature (room temperature) which is $29.85{ }^{\circ} \mathrm{C}$ and continues to be stable until 240 seconds. Afterwards, the temperature rises to $30.85^{\circ} \mathrm{C}$ at 264 seconds

TABLE V. MOTOR TERMINATION WITHOUT LOAD

\begin{tabular}{|c|c|c|c|c|c|c|c|}
\hline \multirow{2}{*}{ No. } & \multirow{2}{*}{ Current Setting (A) } & \multicolumn{3}{|c|}{ Motor Current (A) } & \multirow{2}{*}{ Speed } & \multirow{2}{*}{ Temperature } & \multirow{2}{*}{ Termination Response } \\
\hline & & $\mathrm{R}$ & $\mathrm{S}$ & $\mathrm{T}$ & & & \\
\hline 1 & 0.145 & 0.147 & 0.153 & 0.147 & 1638 & 28.85 & Work \\
\hline 2 & 0.150 & 0.147 & 0.153 & 0.147 & 1638 & 28.85 & Work \\
\hline 3 & 0.155 & 0.147 & 0.153 & 0.147 & 1638 & 28.85 & Failed \\
\hline
\end{tabular}

TABLE VI. Motor TERMinATION WITH LOAD

Whereas in Table 6 . is the test data on the same 3 phase motor and the same Imax setting on the motor load

\begin{tabular}{|c|c|c|c|c|c|c|c|}
\hline \multirow{2}{*}{ No. } & \multirow{2}{*}{ Current Setting (A) } & \multicolumn{3}{|c|}{ Motor Current (A) } & \multirow{2}{*}{ Speed (Rpm) } & \multirow{2}{*}{ Temperature } & \multirow{2}{*}{ Termination Response } \\
\hline & & $\mathrm{R}$ & $\mathrm{S}$ & $\mathrm{T}$ & & & \\
\hline 1 & 0,21 & 0,203 & 0,211 & 0,214 & 1037 & 31,85 & Work \\
\hline 2 & 0,235 & 0,214 & 0,22 & 0,234 & 126 & 33,85 & Work \\
\hline 3 & 0,24 & 0,236 & 0,245 & 0,252 & 1020 & 35,85 & Work \\
\hline
\end{tabular}


and then rises again to $31.85{ }^{\circ} \mathrm{C}$ at 438 seconds, after the current reaches or exceeds $0.21 \mathrm{~A}$ and the temperature reaches or exceeds $31.85{ }^{\circ} \mathrm{C}$ the motor will stop due to the disconnection response. However, when the temperature is on $31.85{ }^{\circ} \mathrm{C}$, the temperature will limit at the current setting $0.21 \mathrm{~A}$.

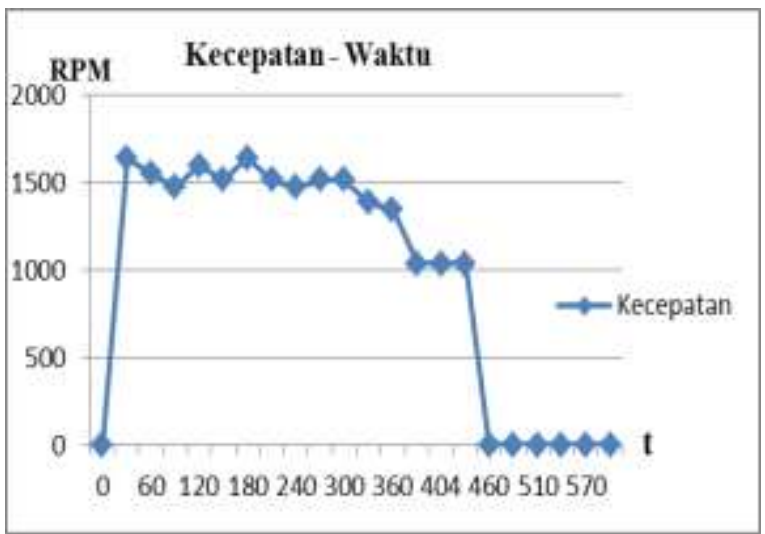

Fig. 7. Speed chart at current setting $0.21 \mathrm{~A}$

In Figure 7. is a graph at the current setting $0.21 \mathrm{~A}$ with motor speed when there is a break of 1037 RPM at 430 seconds. The graph shows when the motor current approaches the setting current which causes the speed decreases and eventually stops or equal to 0 . Whereas, when the current has exceeded the current limit and temperature setting so that the motor stops due to the response of the disconnection of the relay.

Figure 6 and Figure 7 refer to Table 6. which previously explained how the temperature responds to time and the speedy response to time. Based on Figure 2 and Figure 3 shows a graph of temperature and speed concerning to a time when there is a break at the same time which is approximately 430 seconds. For the speed of the value after a direct termination to 0 RPM and for a fixed temperature is on $31.85^{\circ} \mathrm{C}$. This is happened because of the heat occured in the motor requires some time to be down so that the temperature sensor still reads on $31.85{ }^{\circ} \mathrm{C}$. In addition, the motor temperature test must refer to Indonesian National Standard (SNI) which stipulates that the measurement of the windings must apply a resistance method [9].

\section{CONCLUSION}

After testing on a 3 phase squirrel cage induction motor with 100 Watts power, that works at a frequency of 50 $\mathrm{Hz}$. It can be concluded that the creation of a safety system to detect over current which occurs in the motor 3 phase induction squirrel cage can be completed and b can work as it is. Though it is still found a percent error value in it.

\section{REFERENCES}

[1] Paulus Yuliantoro "Pengaman Motor Listrik 3 Phasa Dengan Sensor Suhu IC LM35" Universitas Sanata Dharma Yogjakarta, 2013.

[2] Aji, Zaenal Panutup "Teknik Pengukuran Temperature Belitan Motor Induksi Menggunakan Metode Resistansi", Balai Riset dan Standarisasi Industri Surabaya, 2014.

[3] Wahjono Endro "Rancang Bangun Relay Pengaman untuk Mengatasi Gangguan Motor Induksi 3 Phase”, Jurusan Teknik Elektro Industri, PENS, 2014.

[4] Tukananto Andri "Rancang Bangun Sistem Proteksi Arus Lebih Motor 3 Fasa Dengan Timer Start dan Trip", Jurusan Teknik Elektro Industri, Fakultas Teknik Universitas Tanjungpura, 2015.

[5] Tiyono "Perancangan Setting Rele Proteksi Arus Lebih Pada Motor Listrik Industri", Jurusan Teknik Elektro dan Teknologi Informasi, Fakultas Teknik, Universitas Gadjah Mada Yogyakarta, 2013.

[6] Sholeh Moh. "Rancang Bangun Sistem Kontrol dan Proteksi Motor Listrik Terhadap Panas (Overheating) serta Peringatan Dini terhadap Gangguan Tegangan dan Arus Berbasis AtMega 328”, Jurusan Teknik Elektro, Universitas Islam Lamongan, 2018.

[7] Didit Very Kuswoyo "Sistem Proteksi Motor Induksi Tiga Fasa Dari Gangguan Tidak Seimbang Dan Temperatur Lebih Menggunakan Mikrokontroller", Universitas Lampung, Bandar Lampung, 2016.

[8] Data Sheet salah satu Produsen Thermistor MURATA Part No. NXFT15XH103).

[9] Standar Nasional Indonesia (SNI) IEC 60335-1 : 2009, Badan Standarisasi Nasional, Jakarta-Indonesia, 2009.

[10] NEMA (The National Elektrical Manufacture Association) 